\title{
Appendix: sources of documents
}

This list of sites is not intended to be exhaustive. However, it is provided here as a means to provide ideas about the range of materials available.

\section{Business directories}

https://www.uksmallbusinessdirectory.co.uk/ - Small and medium-sized business directory for the UK. Other directories can sometimes be found using the term 'Small and medium-sized business directory' followed by 'in [the country in which you are interested]'.

\section{Government/official/regulator sources}

(Not an exhaustive list.)

https://www.gov.uk/government/statistics - government, primarily statistics, not qualitative;

https://www.gov.uk/ - range of information;

https://www.parliament.uk/business/publications/ - $\quad$ government publications;

Hansard - https://hansard.parliament.uk/ - for verbatim reports of Parliamentary debates;

National Audit Office - https://www.nao.org.uk/ - source of reports on government expenditure;

Parliamentary reports. 


\section{Newspapers}

(Not an exhaustive list.)

British Newspaper Archive - allows you to search individual newspapers - https://www.britishnewspaperarchive.co.uk/;

NewsBank - http://www.newsbank.com/libraries - archives that allow search of topics from a broad range of newspapers and other resources.

\section{Markets}

London Stock Exchange - contains a range of documents on company profiles, functioning of AIM, etc. - https://www.londonstockexchange .com/home/homepage.htm;

The Intercontinental Exchange - contains a range of documents relating to the trading of derivatives - https://www.theice.com/futures-europe.

\section{Professional bodies}

Websites of recognized institutes representing professional bodies that contain a host of information about their respective professions:

Institute of Chartered Accountants in England and Wales - https://www .icaew.com/library/historical-resources/guide-to-historical-resources;

Association of Chartered Certified Accountants - https://www.accaglobal .com/uk/en.html;

Chartered Institute of Management Accountants - https://www .cimaglobal.com/;

Institute of Chartered Accountants in Scotland - https://www.icas.com/; 
Chartered Institute of Professional Development: https://www .cipd.co.uk/?gclid=EAIaIQobChMIkvfulqDa6wIVDbTtCh1kTw _vEAAYASAAvEAA2_D_BwE;

Association for Project Management - https://www.apm.org.uk/.

\section{Review websites}

These may exist in a wide range of areas. Some that are particularly useful for different reasons are:

Indeed - This website provides advertisements of job vacancies. However, one of its best resources for research purposes is its review sections by existing and former employees of jobs that appear on the website. The review section may be found at: https://www.indeed.co.uk/companies ?from=gnav-acme--discovery-webapp.

MyBuilder - This website provides consumers' reviews of builders who have conducted a similar building or home maintenance job to the one that a user is seeking to have done. The website may be found at: https://www.mybuilder.com/?adgroup_id=brandbmm\&gclid=EAIaI QobChMIgvHqvOOV6wIVT-3tCh25FAkuEAAYAyAAEgJNC_D_BwE.

Tripadvisor - This website provides customer reviews of a range of leisure activities including hotels, holiday rentals, restaurants and travel arrangements in a range of different countries. The website providing access to its fora may be found at: https://www.tripadvisor.co.uk/ForumHome.

Trustpilot - This website provides customer reviews of a full range of businesses, internationally. The website providing access to its fora may be found at: https://uk.trustpilot.com/.

\section{Information on China}

(Available in English, not an exhaustive list.) 
The sources that are listed above are either generic or specific to the United Kingdom. There are corresponding sources in other countries and each country also tends to have sources of documents on other countries. For example, in the UK, sources that are available in the English language from China, or are produced about China in English, include the following:

National Bureau Statistics of China - http://www.stats.gov.cn/english/ primarily statistics, not qualitative;

China Centre Library at the University of Oxford - https://www.bodleian .ox.ac.uk/ccl/e-resources;

UKIRA - http://www.asiamap.ac.uk/ - this is the directory of UK information resources on Asia and contains details of newspapers, electronic resources and other material, including on China.

\section{International}

International Labour Organization - https://www.ilo.org/global/ publications/lang--en/index.htm - concerns with labour;

The World Bank - https://data.worldbank.org/ - provides a wide range of data on global development.

\section{Tracking facilities}

There are many websites that allow the tracking of when there are new publications of documents that could be useful to collect in the types of research described below. These include TheyWorkForYou (https://www .theyworkforyou.com/) which enables you to set up alerts about when a particular topic is discussed in Parliament; and the Bank of England and its various committees (https://www.bankofengland.co.uk/subscribe -to-emails). A particularly useful source that allows signing up for email notifications from a range of different bodies is govDelivery (https:// service.govdelivery.com/session/new). 